Article

\title{
Assessment of the Impact of a Motorway on Content and Spatial Distribution of Mercury in Adjacent Agricultural Soils
}

\author{
Hanna Jaworska * ${ }^{D}$ and Joanna Klimek \\ Department of Soil Science and Biochemistry, Faculty of Agriculture and Biotechnology, \\ Bydgoszcz University of Science and Technology, Bernardynska St.6, 85-029 Bydgoszcz, Poland; \\ klimek188@wp.pl \\ * Correspondence: hanna.jaworska@pbs.edu.pl
}

Citation: Jaworska, H.; Klimek, J. Assessment of the Impact of a Motorway on Content and Spatial Distribution of Mercury in Adjacent Agricultural Soils. Minerals 2021, 11, 1221. https://doi.org/10.3390/ $\min 11111221$

Academic Editor: Pedro Tume

Received: 13 September 2021

Accepted: 29 October 2021

Published: 2 November 2021

Publisher's Note: MDPI stays neutral with regard to jurisdictional claims in published maps and institutional affiliations.

Copyright: (c) 2021 by the authors. Licensee MDPI, Basel, Switzerland. This article is an open access article distributed under the terms and conditions of the Creative Commons Attribution (CC BY) license (https:// creativecommons.org/licenses/by/ $4.0 /)$.

\begin{abstract}
The distribution of $\mathrm{Hg}$ in the vicinity of roads is probably not exclusively dependent on car emissions, but also on the presence of other point or diffuse sources of $\mathrm{Hg}$ emissions located from metres to several $\mathrm{km}$ away. The source of mercury in urbanised areas is pollution derived from the burning of fuels and industrial and transport waste, while in agricultural areas, it is constituent in mineral fertilisers and crop protection products. The research objective was to evaluate the content and spatial distribution of mercury in arable soils adjacent to the A1 motorway in Poland. The research material consisted of 40 soil samples taken from 20 test points on four transects at distances of 5, 10, 25 and $50 \mathrm{~m}$ from a noise barrier and in the direction of an arable field, and $10 \mathrm{~m}$ from the noise barrier in the direction of the motorway. Total mercury content was determined by atomic absorption spectrometry using an AMA 254 analyser. The spatial relationship between adjacent observations of variables was assessed using Moran's I overall autocorrelation coefficient. Probability maps of mercury distribution in the field and pollution indicators were elaborated in ArcGIS 10.4.1. using Inverse Distance Weighted interpolation. Analysis of the spatial correlation of Moran's I showed a lack of spatial dependence between tested points, which may evidence that the motorway does not affect mercury contents in the soil. The elevated mercury content at a single test point may indicate a random event unrelated to the motorway's operation.
\end{abstract}

Keywords: mercury in agricultural soils; highway traffic pollution; Moran's I autocorrelation coefficient; pollution index

\section{Introduction}

Mercury is considered to be a major hazardous substance due to its toxicity, mobility and long atmospheric residence time [1-3]. The presence of mercury in the soil environment may be caused by natural or anthropogenic factors [4]. The source of mercury in urbanised areas is pollution derived from the burning of fuels and industrial and transport waste, while in agricultural areas, it is constituent in mineral fertilisers and crop protection products. The activity of industrial facilities such as coal-fired power plants, coking plants and cement works constitute, in combination with car traffic, the anthropogenic sources of mercury in road dust [5]. Civilisational development and improvements in living conditions entail the need for a road network in agricultural areas, which causes sources of pollution to accumulate. Vehicle exhaust fumes are a stress factor that can negatively impact soil productivity. Higher vehicle velocities increase exhaust emissions, which contain heavy metals, among other compounds [6]. Interior vehicle lights and high-intensity dischargetype headlamps are also responsible for mercury pollution in roadside soil [7]. Studies about $\mathrm{Hg}$ content in soils from urbanized areas are scarce, but different works have found high levels of $\mathrm{Hg}$ in soils adjacent to roads. Moreover, the presence of mercury in crude oil and its derivatives that has been indicated by researchers [8,9] justifies research into its contents and spatial distribution in soils adjacent to motorways. The average share of particulate mercury depends on the research areas. Its concentration is significantly higher 
in urbanized areas than in agricultural areas [10-12]. Deposition of particulate mercury is an important part of its migration in the environment. In 2008, the following classification was adopted in a UNEP report (2008) [13], which distinguished three emission sources: current emissions from natural sources, current emissions from anthropogenic sources, and re-emissions from historical deposits from natural and anthropogenic sources. Secondary enrichment mechanisms-sorption, conversion at the solid-air interface are thought to have a significant impact on the concentration and speciation of particulate mercury in dust. Directive 2010/75/UE [14] has been developed, where regulations 595/2009 and 459/2012 specify emission requirements for motor vehicles (Euro 6). The mercury content in crude oil can even exceed $2 \mathrm{mg} \cdot \mathrm{kg}^{-1}[15,16]$. The main task for improving our knowledge of mercury sources, fates, impacts, and emission control options was defined at the 14th ICMGP Conference in 2019 as bridging knowledge on global mercury with environmental responsibility, human welfare and policy response. Mercury, listed as one of the top ten chemicals of concern $(\mathrm{WHO}, 2017)$ is a potentially harmful trace element in the environment.

The research hypothesis assumed that road traffic and the noise barrier would influence the content and spatial distribution of mercury in surrounding soils.

The research objective was to evaluate the content and spatial distribution of mercury in arable soils adjacent to the A1 motorway in Poland.

\section{Materials and Method}

\subsection{Study Area and Sampling Procedur}

The research area is located in central Poland $\left(53^{\circ} 21^{\prime} 14.6^{\prime \prime} \mathrm{N} 18^{\circ} 42^{\prime} 13.1^{\prime \prime} \mathrm{E}\right)$, in the vicinity of the A1 motorway, along international route E75 (Figure 1).

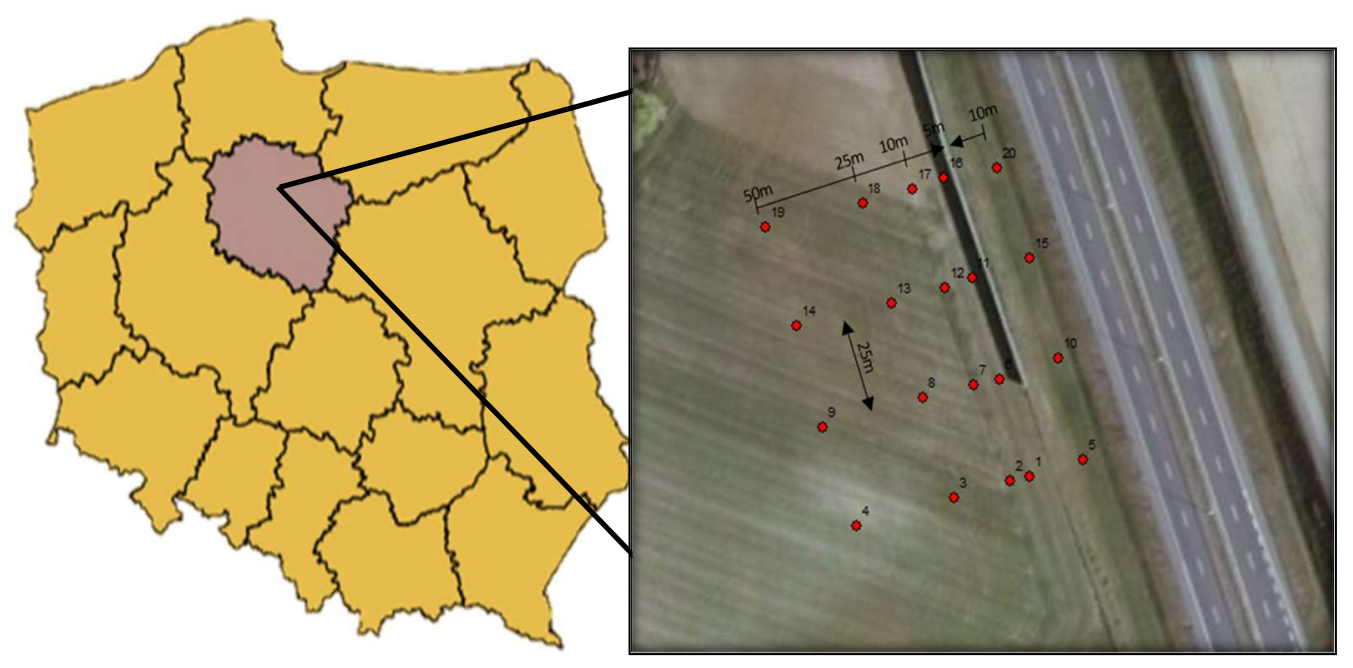

Figure 1. Study area.

The motorway was opened to traffic on 14 October 2011. According to 2015 data from the Directorate General, traffic volume is in excess of 17,000 vehicles per day. The wind direction in the region varies throughout the year: about 35\% westerlies, $25 \%$ easterlies, $20 \%$ northerlies and $20 \%$ southerlies [17]. The investigated agricultural area is separated from the motorway by a noise barrier of steel plates that is about $650 \mathrm{~m}$ long and $4 \mathrm{~m}$ high. The investigated area is covered by Luvisols (IUSS, 2014) formed from glacial till [18]. The presented area was not previously included in the assessment of the impact of anthropogenic factors on the mercury content in soils. This is of key importance due to the intensive agricultural production conducted in this area.

The research material consisted of 40 soil samples taken from 20 test points on four transects at distances of 5, 10, 25 and $50 \mathrm{~m}$ from a noise barrier and in the direction of an arable field, and $10 \mathrm{~m}$ from the noise barrier in the direction of the motorway. Soil samples 
were taken from the surface humic horizon at a depth of $0-20 \mathrm{~cm}$ and from the subsurface layer at $20-40 \mathrm{~cm}$. Additionally, in order to determine the geochemical background, six samples were taken from a depth of $150 \mathrm{~cm}$ (parent rock) at six points randomly located within the research area. These samples were the parent material, in which the content of Fe and $\mathrm{Hg}$ was determined. In the year of sampling, intensive farming was being conducted in the study area (wheat, sugar beet and maize in rotation).

\subsection{Laboratory Analysis:}

\subsubsection{Selected Physical and Chemical Properties}

The following laboratory analyses were carried out in soil samples after initial preparation in accordance with the standard (ISO 11464:2006) [19]: particle-size composition using soil texture by sieving and sedimentation (ISO 11277:2009) [20]; total organic carbon content (TOC) by sulfochromic wet oxidation in a potassium dichromate solution $\left(\mathrm{K}_{2} \mathrm{Cr}_{2} \mathrm{O}_{7}\right)$ (ISO 14235:1998) [21]; potentiometric reaction in a solution of $1 \mathrm{~mol} \cdot \mathrm{dm}^{-3} \mathrm{KCl}$ and $\mathrm{H}_{2} \mathrm{O}$ according to ISO 10390:2005 [22] using a CPC-551 pH meter and calcium carbonate by field method and by the Scheibler volumetric method according to ISO 10693:1995 [23]. All determinations were made with three replicates.

\subsubsection{Mercury Content}

Total mercury content was determined by atomic absorption spectrometry using an AMA 254 analyser (Altec, Czech Republic). The analyser used for the measurements is a single-beam atomic absorption spectrometer with a serial arrangement of two cuvettes. The apparatus is designed for a limit of detection of $0.01 \mathrm{ng}$ of mercury in a sample. The reproducibility of test results is assessed at $<1.5 \%$. The mercury content results are the arithmetic means of replicates not exceeding $5 \%$ of the coefficient of variation. Mercury compounds are highly volatile when heated, which makes analyses hard to conduct correctly. Therefore, to verify the reliability of the mercury analysis procedure, TILL-3 certified reference material (Certificate of Analysis, 1995) was also used for measurements.

\subsection{Statistical and Geostatistical Analyses}

Descriptive statistics parameters (minimum, mean and maximum values, standard $[\mathrm{SD}]$, kurtosis and coefficient of variation [CV]) were presented as the sum of mercury content $\left(\mathrm{mg} \cdot \mathrm{kg}^{-1}\right)$. To determine the correlation between total mercury content and chemical properties, Pearson's correlation coefficient was used $(p<0.05)$. The results were statistically analysed in Statistica 13.1 software (TIBCO Software Inc.) for Windows PL.

The spatial relationship between adjacent observations of variables was assessed using Moran's I overall autocorrelation coefficient [24]. Moran's I global analysis involves identifying spatial patterns in soil chemistry that may be random, scattered or clustered, depending on location and sample values. The research hypothesis was that the mercury content in the entire research area was randomly distributed. Positive values of Moran's I indicate that neighbouring values are similar, suggesting a positive spatial correlation, while negative values indicate that neighbouring values are different, suggesting an inverse correlation. A Moran's I of zero indicates no spatial pattern. Probability maps of mercury distribution in the field and pollution indicators were elaborated in ArcGIS 10.4.1 (Esri). using Inverse Distance Weighted interpolation [25].

\subsection{Pollution Indices}

In order to assess the sources of mercury in the studied soils, the indices used were pollution and the geo-accumulation index. Pollution indices can assess the quality of soils exposed to heavy-metal contamination $[8,26]$. These indices are used in studies of mercury in dust [27] and in soil [28]. To determine the level of mercury contamination in the tested soil samples, the geo-accumulation index (Igeo) and the enrichment factor (EF) were used. These indexes are used to assess the presence and intensity of anthropogenic contaminant deposition on soil. 
The geo-accumulation index [29] is used to define the contamination level of a single element. It is used to compare contents of metallic elements in tested soil material against natural metal concentrations. The formula used was:

$$
\text { Igeo }=\log [\mathrm{Cn} /(1.5 \times \mathrm{Bn})]
$$

where:

$\mathrm{Cn}=$ Measured concentration of heavy metal

$\mathrm{Bn}=$ Geochemical background value

$\mathrm{Cn}$ refers to calculated values and $\mathrm{Bn}$ to background values. The factor 1,5 is applied to order control the variations of $B n$ values caused by the environment. The factor 1.5 allows for involving natural fluctuations in the concentration of a given substance in the environment and very small anthropogenic influences. The applied geochemical background values were derived from the analysis of the determined content in the parent material.

Geo-accumulation index [29]

Igeo $\leq 0$-Unpolluted

$0<$ Igeo $<1$-Unpolluted to moderately polluted

$1<$ Igeo $<2-$ Moderately polluted

$2<$ Igeo $<3-$ Moderately to highly polluted

$3<$ Igeo $<4$ - Highly polluted

$4<$ Igeo $<5$ - Highly to extremely polluted

Igeo $\geq 5$-Extremely polluted

The normalised enrichment factor is used to determine differences in contents between metals from anthropogenic and natural environmental sources. It is also used to assess the distribution of metallic elements in different genetic layers of soils. It involves comparing the concentration of one element to another that is particularly stable and poorly mobile in soil. The selected component should also be bound to finer particles (depending on grain size), and its concentrations should be immune to human impact [30]. The conservative element most commonly used in soil contamination research is iron [31]. Other elements used in many studies are $\mathrm{Al}, \mathrm{Mn}$ and $\mathrm{Rb}$, and total organic carbon [30,32]. The calculations employ the content of individual metals defined as the background value. The formula used was:

$$
\mathrm{EF}=\frac{(\mathrm{M} / \mathrm{Fe}) \text { in a genetic layer }}{(\mathrm{M} / \mathrm{Fe}) \text { background value }}
$$

where:

M-total metal content,

$\mathrm{Fe}-$ total iron content.

According to Chen et al., EF values were divided into seven classes in which:

$\mathrm{EF}<1$ does not indicate enrichment;

$\mathrm{EF}<3$ is slight enrichment;

$\mathrm{EF}=3-5$ is moderate enrichment;

$\mathrm{EF}=5-10$ is moderately severe enrichment;

$\mathrm{EF}=10-25$ is severe enrichment;

$\mathrm{EF}=25-50$ is very severe enrichment;

$\mathrm{EF}>50$ is extremely severe enrichment.

An enrichment factor above 1.5 indicates anthropogenic accumulation of metallic elements [33].

\section{Results}

Grain-size composition tests were used to determine groups and subgroups of soil material in the surface and subsurface layers of the analysed soils. The soils were sandy loam and sandy clay loam (USDA, 2012). The sand fraction is the largest grain-size fraction in both layers, followed by silt and clay. The analysed samples contained $57.0-72.0 \%$ sand fraction, $16.0-26.0 \%$ silt and $7.0-21.0 \%$ clay. By agrotechnical soil weight category (PTG, 
2008), they are classed as medium soils (Table 1 ). In the samples, $\mathrm{pHH} 2 \mathrm{O}$ ranged from 6.0 to 8.0 , while $\mathrm{pHKCl}$ ranged from 5.3 to 7.4 , indicating acid to alkaline reaction. $\mathrm{CaCO} 3$ content ranged from $<1$ to $6.4 \%$ [31] (Table 1). Total organic carbon content (TOC) ranged from 1.8 to $10.7 \mathrm{~g} \cdot \mathrm{k}^{-1}$ in surface layer samples and from 0.9 to $9.3 \mathrm{~g} \cdot \mathrm{k}^{-1}$ in subsurface samples [34].

Table 1. Selected physical and chemical properties of soils.

\begin{tabular}{|c|c|c|c|c|c|}
\hline No & $\begin{array}{c}\text { Depth } \\
{[\mathrm{cm}]}\end{array}$ & $\begin{array}{c}\mathrm{pH} \\
\mathrm{H}_{2} \mathrm{O}\end{array}$ & $\begin{array}{c}\mathrm{pH} \\
\mathrm{KCl}\end{array}$ & $\begin{array}{c}\text { TOC } \\
{\left[\text { g.kg }^{-1}\right]}\end{array}$ & $\begin{array}{c}\mathrm{CaCO}_{3} \\
{[\%]}\end{array}$ \\
\hline \multirow{2}{*}{1} & $0-20$ & 7.6 & 7.2 & 3.8 & $<1$ \\
\hline & $20-40$ & 7.6 & 7.2 & 2.6 & $<1$ \\
\hline \multirow{2}{*}{2} & $0-20$ & 7.0 & 6.5 & 8.6 & $<1$ \\
\hline & $20-40$ & 7.3 & 6.8 & 5.4 & $<1$ \\
\hline \multirow{2}{*}{3} & $0-20$ & 7.1 & 6.5 & 4.2 & $<1$ \\
\hline & $20-40$ & 7.0 & 6.3 & 2.7 & $<1$ \\
\hline \multirow{2}{*}{4} & $0-20$ & 7.1 & 6.5 & 2.7 & $<1$ \\
\hline & $20-40$ & 7.2 & 6.8 & 9.3 & $<1$ \\
\hline \multirow{2}{*}{5} & $0-20$ & 7.4 & 7.1 & 9.3 & 1.3 \\
\hline & $20-40$ & 7.5 & 7.2 & 5.6 & 1.4 \\
\hline \multirow{2}{*}{6} & $0-20$ & 7.4 & 7.1 & 3.9 & $<1$ \\
\hline & $20-40$ & 7.1 & 6.4 & 2.0 & $<1$ \\
\hline \multirow{2}{*}{7} & $0-20$ & 7.4 & 7.0 & 2.9 & $<1$ \\
\hline & $20-40$ & 7.1 & 6.3 & 1.9 & $<1$ \\
\hline \multirow{2}{*}{8} & $0-20$ & 7.3 & 6.9 & 2.1 & $<1$ \\
\hline & $20-40$ & 7.2 & 6.8 & 3.2 & $<1$ \\
\hline \multirow{2}{*}{9} & $0-20$ & 7.6 & 7.2 & 1.8 & 4.6 \\
\hline & $20-40$ & 7.7 & 7.3 & 1.5 & 5.3 \\
\hline \multirow{2}{*}{10} & $0-20$ & 7.6 & 7.3 & 4.6 & 1.4 \\
\hline & $20-40$ & 8.0 & 7.4 & 0.9 & 5.6 \\
\hline \multirow{2}{*}{11} & $0-20$ & 7.2 & 6.9 & 5.5 & $<1$ \\
\hline & $20-40$ & 7.1 & 6.6 & 4.0 & $<1$ \\
\hline \multirow{2}{*}{12} & $0-20$ & 7.3 & 7.1 & 7.7 & $<1$ \\
\hline & $20-40$ & 7.3 & 7.0 & 6.5 & $<1$ \\
\hline \multirow{2}{*}{13} & $0-20$ & 7.5 & 7.1 & 6.3 & 1.3 \\
\hline & $20-40$ & 7.5 & 7.2 & 7.6 & 1.5 \\
\hline \multirow{2}{*}{14} & $0-20$ & 7.3 & 6.8 & 4.6 & $<1$ \\
\hline & $20-40$ & 7.2 & 6.8 & 4.9 & $<1$ \\
\hline \multirow{2}{*}{15} & $0-20$ & 7.8 & 7.3 & 1.9 & 2.3 \\
\hline & $20-40$ & 7.7 & 7.3 & 1.5 & 2.8 \\
\hline \multirow{2}{*}{16} & $0-20$ & 7.1 & 6.8 & 4.3 & $<1$ \\
\hline & 20-40 & 7.2 & 6.8 & 5.7 & $<1$ \\
\hline \multirow{2}{*}{17} & $0-20$ & 6.0 & 5.3 & 6.9 & $<1$ \\
\hline & 20-40 & 6.4 & 5.6 & 5.6 & $<1$ \\
\hline \multirow{2}{*}{18} & $0-20$ & 7.4 & 7.2 & 4.9 & 1.3 \\
\hline & $20-40$ & 7.7 & 7.3 & 6.2 & 3.9 \\
\hline \multirow{2}{*}{19} & $0-20$ & 6.9 & 6.8 & 10.7 & $<1$ \\
\hline & $20-40$ & 7.4 & 6.6 & 3.9 & $<1$ \\
\hline \multirow{2}{*}{20} & $0-20$ & 7.6 & 7.2 & 3.6 & 2.0 \\
\hline & $20-40$ & 7.9 & 7.3 & 2.9 & 6.4 \\
\hline
\end{tabular}


The tested soils have low TOC content: in most samples, TOC is below $2.2 \%$ value, the assumed average value for Poland [35,36].

Total mercury content ranged from 0.013 to $0.041 \mathrm{mg} \cdot \mathrm{kg}^{-1}$ in surface layers and from 0.013 to $0.059 \mathrm{mg} \cdot \mathrm{kg}^{-1}$ in subsurface layers (Table 2). Soil is a vital resource for humans because its chemical and physical conditions affect agricultural production and the quality of its products. Mercury entrance in the food chain represents a geochemical risk because of toxicity and bioaccumulation phenomena.

Table 2. The content of $\mathrm{Hg}$ and Fe. Calculated geo-accumulation indexes (Igeo) and enrichment factor $(\mathrm{EF})$.

\begin{tabular}{|c|c|c|c|c|c|}
\hline No. & Depth (cm) & $\mathrm{Hg}\left(\mathrm{mg} \cdot \mathrm{kg}^{-1}\right)$ & $\mathrm{Fe}$ & Igeo Index & EF \\
\hline \multirow{2}{*}{1} & $0-20$ & 0.039 & 962.30 & -0.23 & 3.90 \\
\hline & $20-40$ & 0.027 & 957.80 & -0.61 & 2.65 \\
\hline \multirow{2}{*}{2} & $0-20$ & 0.025 & 907.20 & -0.65 & 2.41 \\
\hline & $20-40$ & 0.025 & 908.40 & -0.68 & 2.33 \\
\hline \multirow{2}{*}{3} & $0-20$ & 0.021 & 894.70 & -0.82 & 2.00 \\
\hline & $20-40$ & 0.022 & 877.20 & -0.80 & 2.01 \\
\hline \multirow{2}{*}{4} & $0-20$ & 0.027 & 861.30 & -0.59 & 2.41 \\
\hline & $20-40$ & 0.033 & 866.50 & -0.39 & 2.97 \\
\hline \multirow{2}{*}{5} & $0-20$ & 0.039 & 975.20 & -0.23 & 3.93 \\
\hline & $20-40$ & 0.016 & 1000.60 & -1.14 & 1.63 \\
\hline \multirow{2}{*}{6} & $0-20$ & 0.025 & 1114.10 & -0.66 & 2.93 \\
\hline & $20-40$ & 0.028 & 1116.00 & -0.56 & 3.24 \\
\hline \multirow{2}{*}{7} & $0-20$ & 0.024 & 1115.50 & -0.70 & 2.81 \\
\hline & $20-40$ & 0.025 & 1070.50 & -0.66 & 2.82 \\
\hline \multirow{2}{*}{8} & $0-20$ & 0.024 & 981.90 & -0.70 & 2.47 \\
\hline & $20-40$ & 0.025 & 959.40 & -0.65 & 2.54 \\
\hline \multirow{2}{*}{9} & $0-20$ & 0.021 & 1082.00 & -0.86 & 2.32 \\
\hline & $20-40$ & 0.021 & 1040.20 & -0.85 & 2.25 \\
\hline \multirow{2}{*}{10} & $0-20$ & 0.024 & 946.90 & -0.70 & 2.39 \\
\hline & $20-40$ & 0.022 & 1053.60 & -0.78 & 2.46 \\
\hline \multirow{2}{*}{11} & $0-20$ & 0.032 & 935.10 & -0.41 & 3.16 \\
\hline & $20-40$ & 0.036 & 923.90 & -0.30 & 3.48 \\
\hline \multirow{2}{*}{12} & $0-20$ & 0.028 & 981.50 & -0.56 & 2.85 \\
\hline & $20-40$ & 0.029 & 992.90 & -0.52 & 3.01 \\
\hline \multirow{2}{*}{13} & $0-20$ & 0.025 & 1086.60 & -0.66 & 2.86 \\
\hline & $20-40$ & 0.034 & 981.90 & -0.37 & 3.45 \\
\hline \multirow{2}{*}{14} & $0-20$ & 0.022 & 971.70 & -0.80 & 2.21 \\
\hline & $20-40$ & 0.018 & 960.60 & -0.97 & 1.84 \\
\hline \multirow{2}{*}{15} & $0-20$ & 0.025 & 991.60 & -0.67 & 2.59 \\
\hline & $20-40$ & 0.013 & 972.00 & -1.30 & 1.34 \\
\hline \multirow{2}{*}{16} & $0-20$ & 0.029 & 886.70 & -0.51 & 2.69 \\
\hline & $20-40$ & 0.037 & 921.90 & -0.26 & 3.60 \\
\hline
\end{tabular}


Table 2. Cont.

\begin{tabular}{cccccc}
\hline No. & Depth $(\mathbf{c m})$ & Hg $\left(\mathbf{m g} \cdot \mathbf{k g} \mathbf{- 1}^{\mathbf{1}}\right.$ & $\mathbf{F e}$ & Igeo Index & EF \\
\hline \multirow{2}{*}{17} & $0-20$ & 0.032 & 831.40 & -0.42 & 2.78 \\
\cline { 2 - 6 } & $20-40$ & 0.033 & 829.80 & -0.39 & 2.85 \\
\hline \multirow{2}{*}{18} & $0-20$ & 0.041 & 1001.20 & -0.18 & 4.25 \\
\cline { 2 - 5 } & $20-40$ & 0.059 & 1024.30 & 0.19 & 6.31 \\
\hline \multirow{2}{*}{19} & $0-20$ & 0.025 & 1067.20 & -0.66 & 2.80 \\
\cline { 2 - 6 } & $20-40$ & 0.030 & 1107.30 & -0.49 & 3.43 \\
\hline \multirow{2}{*}{20} & $0-20$ & 0.013 & 942.70 & -1.29 & 1.31 \\
\cline { 2 - 5 } & $20-40$ & 0.018 & 952.50 & -0.97 & 1.83 \\
\hline
\end{tabular}

The elevated mercury content in dust indicated by researchers $[5,27]$ in an area influenced by vehicular traffic may be the cause of the even distribution of mercury contamination in the soil in the immediate vicinity of the motorway. The data from the present study have a fairly uniform distribution (heavily right-skewed), which differs from a normal distribution. A significant data amplitude and high skewness and kurtosis coefficient values were noted (Figure 2).

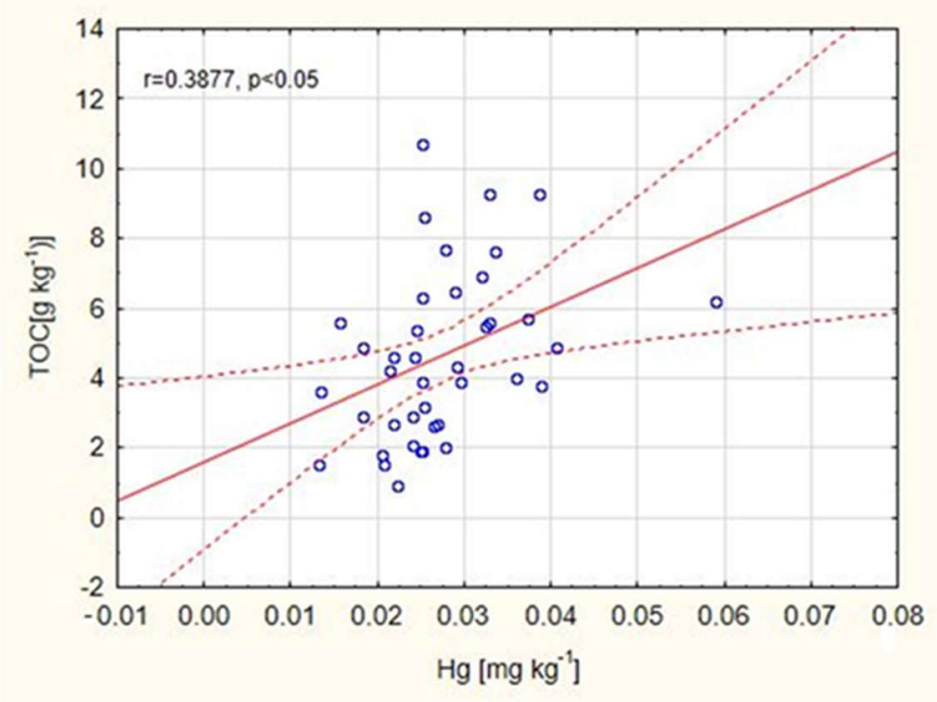

Figure 2. Correlation with a significant relationship between the TOC content and the total content of mercury.

Mercury contents were lower and less variable in the surface layer than in the subsurface layer. The correlation coefficients (Table 3) confirmed a significant positive relationship between total carbon content and total mercury content $(\mathrm{r}=0.3878 ; p<0.05)$, which is confirmed by previous studies [28,37]. A positive correlation between the level of $\mathrm{Hg}$ and the amount of organic matter has been confirmed by studies conducted on natural (non-agricultural) soils, while in cultivated soils no such correlation has been found, which may be due to the impact of agrotechnical treatments, which generally reduce the organic matter content of soil and increase exposure to air. 
Table 3. Statistical parameters.

\begin{tabular}{|c|c|c|c|c|c|c|c|}
\hline \multirow{2}{*}{$\begin{array}{c}\text { Element } \\
\mathrm{Hg} \mathrm{mg/kg}\end{array}$} & \multicolumn{7}{|c|}{ Statistical Parameters } \\
\hline & Average & Min & Max. & SD & Skewness & Kurtosis & CV (\%) \\
\hline $0-20 \mathrm{~cm}$ & 0.028 & 0.013 & 0.046 & 0.007 & 0.82 & 1.37 & 26.61 \\
\hline $20-40 \mathrm{~cm}$ & 0.028 & 0.013 & 0.059 & 0.01 & 1.58 & 4.45 & 36.03 \\
\hline
\end{tabular}

The soil texture has significant effects on the $\mathrm{Hg}$ content in soil. The concentrations of $\mathrm{Hg}$ and other heavy metals in soils generally tend to increase with decreasing grain size, which is due to the propensity of metals to bind with finer particles [38].

However, no relationship between mercury content and colloidal clay content was confirmed (Figure 2). According to Polish regulations (Regulation, 2016) [39], the investigated area qualifies as uncontaminated by mercury. Moreover, the values were determined to be typical of uncontaminated soils in Europe [40]. The average for European topsoil $\mathrm{Hg}$ concentrations was $0.04 \mathrm{mg} \mathrm{kg}^{-1}$, with a range of $0-159 \mathrm{mg} \mathrm{kg}^{-1}$ [41]. The average mercury content in the analysed samples was lower than that recorded by Kobierski et al. (2016) [28] in agricultural soils in Pomorze and Kujawy. A higher average mercury content was also recorded by Jezierski et al. (2011) [42] in southern Poland. The mercury concentration in the study area was similar to that recorded by Kobierski and Malczyk (2016) [28] in soils of hunting grounds, and in urban soils tested by Różański et al. (2015) [43].

However, it was lower than the mean values $\left(0.316 \mathrm{mg} \cdot \mathrm{kg}^{-1}\right)$ recorded in an industrialised zone of Beijing investigated by Guo-Li et al. (2014), [44] and Luo et al. (2008) [25]. In terms of the vertical distribution of mercury, in the case under study there is no such relationship as that indicated by Wang et al. (2012) [1], who showed that the concentration of mercury was greatest in the arable layer (0-20), which mainly evidenced the external source of this element in the soil. The natural mercury content in Poland, i.e., the background value for soils, is $0.05 \mathrm{mg} \cdot \mathrm{kg}^{-1}$ [45]. Salminen (2005) [40] reports lower background mercury levels $\left(0.017 \mathrm{mg} \cdot \mathrm{kg}^{-1}\right)$ in some regions of Poland. The present analyses indicate that in much of the study area, mercury concentrations do not exceed background levels. At only one test point in the subsurface layer did values slightly exceed background levels (Table 2). The spatial distribution of mercury and the selected indices (Igeo and EF) indicate that mercury contamination is lowest nearest to the motorway, which excludes the road as a source of mercury in this area. The geo-accumulation coefficient shows no harmful values.

Enrichment factors are used to indicate an exogenic origin (atmosphere) to soils with background contents of the metal considered ( $\mathrm{Hg}$ in this case), that is not enriched due to the lithology, but you can never distinguish from a natural or an anthropogenic origin of that metal [46].

The enrichment factor indicates a natural or moderate source of this element in the field, except at one point, where the contamination factor was very high. To illustrate the spatial differentiation in total mercury content and the selected indices in the studied soils, a map was drawn up, for which the input point data were interpolated using Inverse distance weighting (IDW) (Figure 3).

The spatial distribution is in line with the increased mercury content in the field being a random event and it cannot be associated with the location of the motorway. The lack of spatial correlation is indicated by the Moran analysis performed with the Cluster and Outlier Analysis tool (Anselin Local Morans I) in ArcMap 10.4.1(Esri) (manufacturer or laboratory, city, country).

Hg pollution is a global problem. Mercury is an element related to the intensity of human pressure on the environment. The conducted research allows for the assessment of the impact of road traffic and noise barrier on the level of $\mathrm{Hg}$ concentrations in agricultural soils, which indicates the possibility of $\mathrm{Hg}$ transfer to the human food chain. 


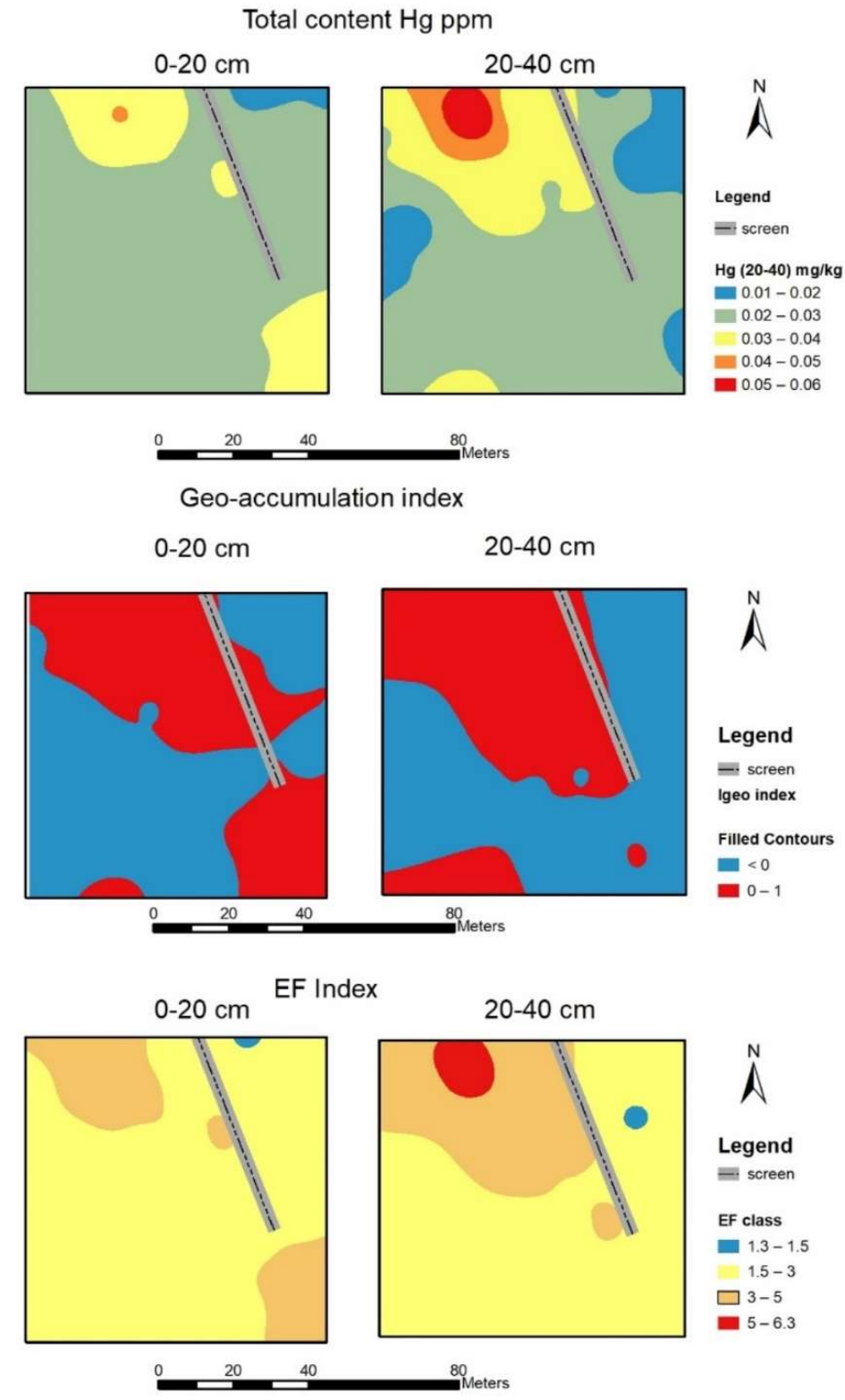

Figure 3. Spatial distribution of $\mathrm{Hg}$ and geo-accumulation index and EF Index.

\section{Conclusions}

1. The total mercury content ranged from 0.013 to $0.041 \mathrm{mg} \cdot \mathrm{kg}^{-1}$ in the surface layers and from 0.013 to $0.059 \mathrm{mg} \cdot \mathrm{kg}^{-1}$ in the subsurface layers, which qualifies the study area as uncontaminated by mercury.

2. The correlation coefficients confirmed a significant positive relationship between total carbon content and total mercury content.

3. The geo-accumulation coefficient shows no harmful values.

4. The enrichment factor indicates a natural or moderate source of this element in the field, except at one point, where the contamination factor was very high.

5. Analysis of Moran's I spatial correlation showed a lack of spatial dependence between tested points, which may evidence that the motorway does not affect mercury contents in the soil.

6. The elevated mercury content at a single test point may indicate a random event unrelated to the motorway's operation. 
7. The geochemical monitoring of soil is important in the aim of evaluating the natural content of mercury in soils, related to parental materials and possible enrichment due to human activities.

Author Contributions: Conceptualisation, H.J.; methodology, H.J.; software, J.K.; validation, H.J. and J.K.; formal analysis, H.J. and J.K.; investigation, H.J. and J.K.; resources, H.J.; data curation, H.J.; writing-H.J. and J.K.; writing—review and editing, H.J.; visualisation, J.K.; supervision, H.J. All authors have read and agreed to the published version of the manuscript.

Funding: This research received no external funding.

Conflicts of Interest: The authors declare no conflict of interest.

\section{References}

1. Wang, J.; Feng, X.; Anderson, C.W.N.; Xing, Y.; Shang, L. Remediation of mercury contaminated sites-A review. Environ. Res. 2012, 125, 113-123. [CrossRef]

2. Rallo, M.; Fuente-Cuesta, A.; Lopez-Anton, M.A.; Díaz-Somoano, M.; Martínez-Tarazona, M.R.; Maroto-Valer, M.M. Speciation of $\mathrm{Hg}$ retained in gasification biomass chars by temperature-programmed decomposition. Fuel Proces. Technol. 2014, 126, 1-4. [CrossRef]

3. Siudek, P.; Falkowska, L.; Brodecka, A.; Kowalski, A.; Frankowski, M.; Siepak, J. Mercury in precipitation over the coastal zone of the southern Baltic Sea, Poland. Environ. Sci. Pollut. Res. 2015, 22, 2546-2557. [CrossRef]

4. Tepanosyan, G.; Sahakyan, L.; Belyaeva, O.; Saghatelyan, A. Origin identification and potentialecological risk assessment of potentially. J. Geochem. Explor. 2016, 67, 1-11. [CrossRef]

5. Lu, X.; Li, L.Y.; Wang, L.; Lei, K.; Huang, J.; Zhai, Y. Contamination assessment of mercury and arsenic in roadway dust from Baoji. Atmos. Environ. 2009, 43, 2489-2496. [CrossRef]

6. Duong, T.T.; Lee, B.K. Determining contamination level of heavy metals in road dust from busy traffic areas with different characteristics. J. Environ. Manag. 2011, 92, 554-562. [CrossRef]

7. Ozaki, H.; Watanabe, I.; Kuno, K. As, $\mathrm{Sb}$ and $\mathrm{Hg}$ distribution and pollution sources in the roadside soil and dust around Kamikochi, Chubu Sangaku National Park, Japan. Geochem. J. 2004, 38, 473-484. [CrossRef]

8. Mazurek, R.; Kowalska, J.; Gąsiorek, M.; Zadrożny, P.; Józefowska, A.; Zaleski, T.; Kępka, W.; Tymczuk, M.; Orłowska, K. Assessment of heavy metals contamination in surface layers of Roztocze National Park forest soils (SE Poland) by indices of pollution. Chemosphere 2017, 168, 839-850. [CrossRef]

9. Kabata-Pendias, A. Trace Elements in Soils and Plants, 4th ed.; CRC Press Taylor \& Francis Group: Boca Raton, FL, USA, 2010; ISBN 9781420093681.

10. Kim, P.-R.; Han, Y.-J.; Holsen, T.M.; Yi, S.-M. Atmospheric particulate mercury: Concentration and size distributions. Atmos. Environ. 2012, 61, 94-102. [CrossRef]

11. Hladikova, V.; Petrik, J.; Jursa, S.; Ursinyova, M.; Kočan, J. Atmospheric mercury levels in the Slovak Republic. Chemosphere 2001, 45, 801-806. [CrossRef]

12. Gworek, B.; Dmuchowski, W.; Baczewska-Dabrowska, A.H. Mercury in the terrestrial environment: A review. Environ. Sci. Europe 2020, 32, 128. [CrossRef]

13. UNEP Chemical Branch. The Global Atmospheric Mercury Assessment: Sources, Emissions and Transport; UNEP-Chemicals: Geneva, Switzerland, 2008.

14. Directive 2010/75/UE on Industrial Emissions (DZ.Urz.UE L 334, 17.12.2010). Available online: https:/ / eur-lex.europa.eu/ LexUriServ/LexUriServ.do?uri=OJ:L:2010:334:0017:0119:en:PDF (accessed on 25 June 2021).

15. Klojzy-Karczmarczyk, B. Assessment of Threats Connected with Contamination of Groundwater with Mercury due to Impact of Selected Road Sections in Central Poland. Annu. Set Environ. Prot. 2011, 13, 1766-1782, (In Polish, abstract In English).

16. Leśniewska, E.; Szynkowska, M.I.; Paryjczak, T. The main sources of mercury in the organisms of people not exposed to work. Annu. Set Environ. Prot. 2009, 11, 403-419.

17. Woś, A. The Climate of Poland in the Second Half of the 20th Century; Scientific Publishing House: London, UK, $2010 ;$ p. 490. ISBN 978832322180.

18. Uniejewska, M. Detailed Geological Map of Poland in the Scale 1: 50,000, Grudziadz Sheet. States; Inst. Geol.: Warszawa, Poland, 1982. (In Polish)

19. ISO 11464. Soil Quality_Pretreatment of Samples for Physico-Chemical Analysis; ISO: Geneva, Switzerland, 2006.

20. ISO 11277. Soil Quality_Determination of Particle Size Distribution in Mineral Soil Material_Method by Sieving and Sedimentation; ISO: Geneva, Switzerland, 2009.

21. ISO 14235. Soil Quality—Determination of Organic Carbon by Sulfochromic Oxidation; ISO: Geneva, Switzerland, 1998.

22. ISO 10390. Soil Quality—Determination of pH; ISO: Geneva, Switzerland, 2005.

23. ISO 10693. Soil Quality_Determination of Carbonate Content-Volumetric Method; ISO: Geneva, Switzerland, 1995.

24. Moran, P.A. Notes on continuous stochastic phenomena. Biometrika 1950, 37, 17-23. [CrossRef] [PubMed] 
25. Luo, W.; Lu, Y.; Wang, B.; Tong, X.; Wang, G.; Shi, Y.; Wang, T.; Giesy, J.P. Distribution and Sources of Mercuryin Soils from Former Industrialized Urban Areas of Beijing, China. Environ. Monit. Assess. 2009, 158, 507-517. [CrossRef]

26. Håkanson, L. An ecological risk index for aquatic pollution control: A sedimentological approach. Water Res. 1980, 14, 975-1001. [CrossRef]

27. Han, X.; Lu, X.; Wu, Y. Health Risks and Contamination Levels of Heavy Metals in Dusts from Parks and Squares of an Industrial City in Semi-Arid Area of China. Int. J. Environ. Res. Public Health 2017, 14, 886. [CrossRef] [PubMed]

28. Kobierski, M.; Malczyk, P. Mercury in the soil of hunting plots and surrounding forests. Sylwan 2016, 160, 433-440.

29. Müller, G. Index of geoaccumulation in sediments of the Rhine River. Geojournal 1969, 2, 108-118.

30. Ackerman, F. A procedure for correcting the grain size effect in heavy metal analyses of estuarine and coastal sediments. Environ. Technol. 1980, 1, 518-527. [CrossRef]

31. Barbieri, M.; Nigro, A.; Sappa, G. Soil contamination evaluation by Enrichment Factor (EF) and Geoaccumulation Index (Igeo). Senses Sci. 2015, 2, 94-97. [CrossRef]

32. Loring, D.H.; Naes, K.; Dahle, S.; Matishow, G.G.; Illin, G. Arsenic, trace metals, and organic micro contaminants in sediments from the Pechora Sea, Russia. Mar. Geol. 1995, 128, 153-167. [CrossRef]

33. Zhang, J.; Liu, C.L. Riverine composition and estuarine geochemistry of particulate metals in China-Weathering features anthropogenic impact and chemical fluxes. Estuar. Coast. Shelf Sci. 2002, 54, 1051-1070. [CrossRef]

34. Różański, S.; Jaworska, H.; Matuszczak, K.; Nowak, J.; Hardy, A. Impact of highway traffic and the acoustic screen on the content and spatial distribution of heavy metals in soils. Environ. Sci. Pollut. Res. 2017, 24, 12778-12786. [CrossRef]

35. Stuczyński, T.; Kozyra, J.; Łopatka, A.; Siebielec, G.; Jadczyszyn, J.; Koza, P.; Doroszewski, A.; Wawer, R.; Nowocień, E. Natural conditions of agricultural production in Poland. Stud. Rep. IUNG-PIB Putawy 2007, 7, 77-115. (In Polish)

36. Krasowicz, S.; Oleszek, W.; Horabik, J.; Dębicki, R.; Jankowiak, J.; Stuczyński, T. Rational management of the soil environment in Poland. Polish J. Agron. 2011, 7, 43-58.

37. Ninkov, J.; Marković, S.; Banjac, D.; Vasin, J.; Milić, S.; Banjac, B.; Mihailović, A. Mercury content in agricultural soils (Vojvodina Province, Serbia). Environ. Sci. Pollution Res. 2016, 139, 73-87. [CrossRef]

38. Boszke, L.; Kowalski, A.; Siepak, J. Grain size partitioning of mercury in sediments of the middle Odra River (Germany/Poland). Water Air Soil Poll 2004, 159, 125-138. [CrossRef]

39. Regulation of the Minister of the Environment Dated 1 September 2016 on Assessment Procedures for the Land Surface Pollution. (Regulation No. 1395). Available online: http:/ / isap.sejm.gov.pl/isap.nsf/download.xsp/WDU20160001395/O/D20161395.pdf (accessed on 10 September 2021).

40. Salminen, R. (Ed.) 2005. Geochemical Atlas of Europe, Part 1. Back-ground Information, Methodology and Maps; Geological Survey of Finland: Espoo, Finland, 2006.

41. Tóth, G.; Hermann, T.; Szatmári, G.; Pásztor, L. Maps of heavy metals in the soils of the European Union and proposed priority areas for detailed assessment. Sci. Total Environ. 2016, 565, 1054-1062. [CrossRef]

42. Jezierski, P.; Kawalko, D.; Kaszubkiewicz, J.; Ochman, D. Comparison of mercury content in agricultural soils of Jelenia Góra and Zabkowice poviats. Prot. Environ. Nat. Resour. 2011, 48, 277-286, (In Polish, abstract In English).

43. Różański, S.; Dabkowska-Naskret, H.; Jaworska, H. Profile distribution of mercury in selected urban soils. Prot. Environ. Nat. Resour. 2015, 26, 1-5. [CrossRef]

44. Guo, P.; Li, Y.; Zhang, Y.X.; Ming, L.; Zhang, S.; Li, Y.M. Effect of freeze-thaw on the adsorption of heavy metals by soil. J. Jilin Univ. (Sci. Ed.) 2012, 50, 593-597.

45. Guédron, S.; Grimaldi, C.; Chauvel, C.; Spadini, L.; Grimaldi, M. Weathering versus atmospheric contributions to mercury concentrations in French Guiana soils. Appl. Geochem. 2006, 21, 2010-2022. [CrossRef]

46. Pasieczna, A. Mercury in soils of urbanized areas in Poland. Geol. Rev. 2012, 60, 46-58. 